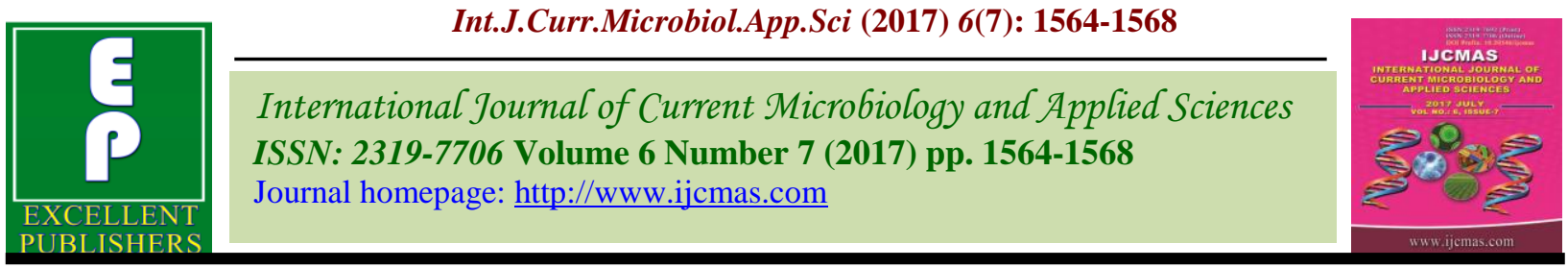

Original Research Article

https://doi.org/10.20546/ijcmas.2017.607.187

\title{
Effect of Biofertilizers and Inorganic Fertilizers on Growth and Yield of Chilli (Capsicum annuum L.)
}

\author{
Holebasappa Kumbar*, A. Chandini Raj and J.K. Hore \\ Department of Spices and Plantation Crops, Bidhan Chandra Krishi Viswavidyalaya, \\ Mohanpur- 741 252, Nadia (West Bengal), India \\ *Corresponding author
}

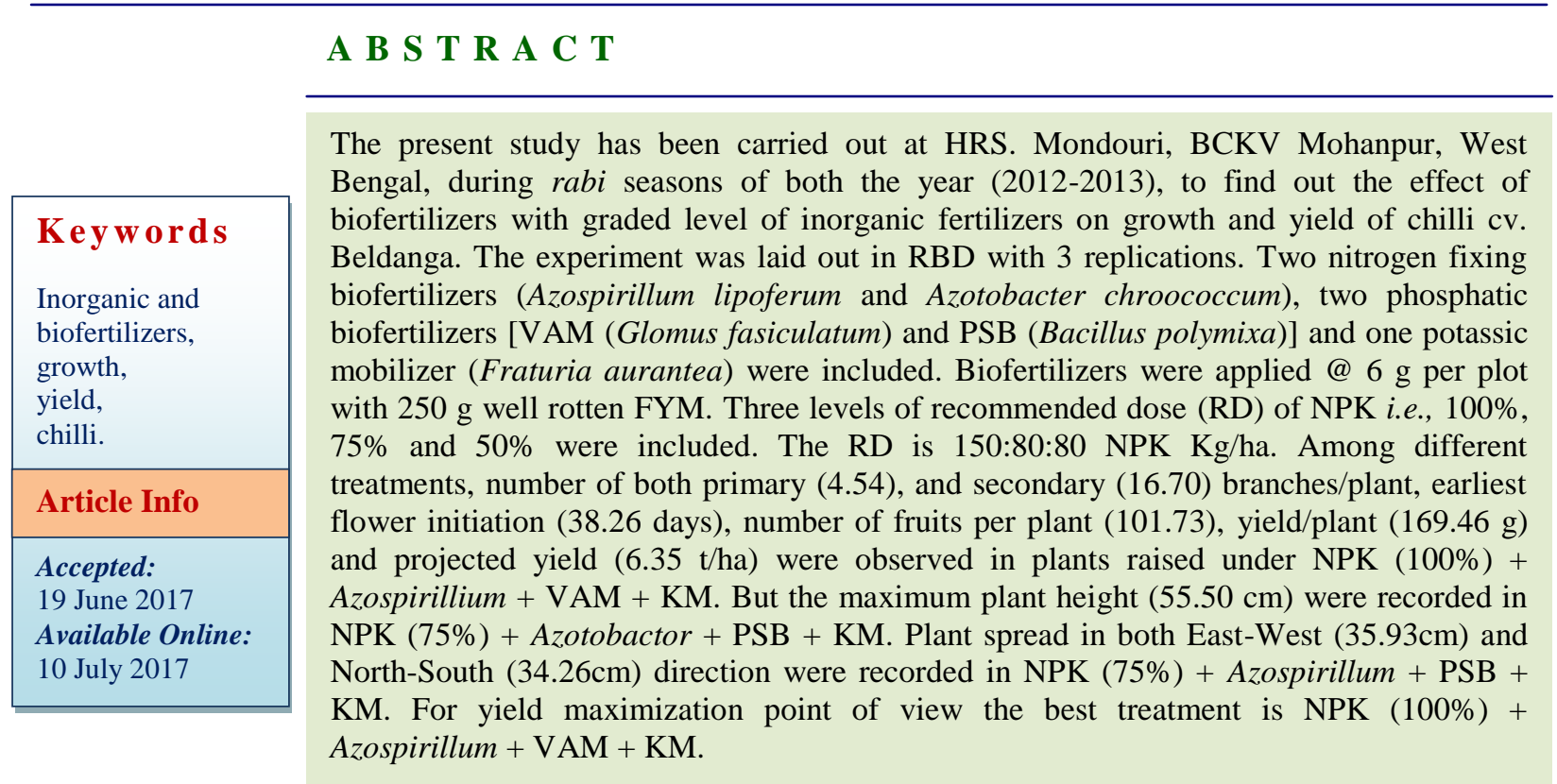

\section{Introduction}

Chilli (Capsicum annuum L.) is the universal spice and widely cultivated throughout temperate, tropical and subtropical countries. It is an indispensable spice due to its pungency, spice, taste, appealing odour and flavour. The dried fruit are extensively used as spices. The ground powder and oleoresin are utilized in pharmaceutical preparations (Warrier, 1989). Nutrient management is one of the most important factor to improve the productivity of chilli. The continuous sole and erratic use of chemical fertilizers in imbalance form leads to decline in soil fertility as well as nutrient uptake efficiency of plants, resulting in either yield stagnation or decrease consequently. In last four decades many microorganisms have been used in the form of biofertilizers. Biofertilizers are eco-friendly, low cost input and not only improve the crop growth and yield but also improve fruit quality and fertilizer use efficiency (Patel et al., 2011). Biofertilizers are the preparations containing living or latent cells of efficient strains of micro organisms capable of fixing atmospheric nitrogen, solubilizing phosphorous and potassium, mobilizing 
nutrients and absorptions of water, decomposing cellulolytic and lignolytic water materials. These micro organisms also produce the growth promoting substances which greatly influences the seed germination, root growth and proliferation.

The Azotobacter and Azospirillum apart from its role in nitrogen fixation from the atmosphere is also involved in production of bioactive substances. Application of phosphate solubilizing microorganisms has given promising response in improving yield of various crops. Mycorrhizal fungi are the distinct symbiotic association between plant roots and soil fungi. Potassium solubilizing biofertilizers are able to solubilize potassium minerals through production and excretion of organic acids (Friedrich et al., 1991). To maintain long term soil health and productivity there is a need for integrated nutrient management through manures and biofertilizers (Mondal et al., 2003). Therefore, the current trend is to explore the possibility of supplementing chemical fertilizers with the biofertilizers. Keeping in this view the present investigation was undertaken to find out the effect of biofertilizers with graded levels of inorganic fertilizers on growth and yield of chilli.

\section{Materials and Methods}

The experiment was undertaken during the rabi season of two consecutive years i.e., 2012-13 and 2013-14, for studying the effect of inorganic and biofertilizers on growth and yield of chilli cv. Beldanga at Horticultural Research Station, Mondouri, Bidhan Chandra Krishi Viswavidylaya, Nadia, West Bengal. The research station was located at $23.5^{0} \mathrm{~N}$ latitude and $89^{\circ} \mathrm{E}$ longitude, with an altitude of $9.75 \mathrm{~m}$ above the mean sea level. It comes under sub-tropical sub humid climatic conditions and Gangetic alluvial soil with sandy clay loam texture and Soil pH 6.9,
Organic carbon (\%) 0.41, Total nitrogen (\%) 0.05, Available phosphorus $\left(\mathrm{kg} \mathrm{ha}^{-1}\right) 21.11$ and Available potassium $\left(\mathrm{kg} \mathrm{ha}^{-1}\right)$ 78.80. The experiment was laid out in randomized block design with 3 replications and 13 treatments (Table 1). Seeds were sown during middle of September in well pulverized raised seed bed. Healthy seedlings were transplanted during middle of November in $2.0 \mathrm{~m} \times 1.6 \mathrm{~m}$ plots at $50 \times 40 \mathrm{~cm}$ spacing, accommodating 16 plants per plot during both the years. Biofertilizers were applied @ 6 g per plot with $250 \mathrm{~g}$ well rotten FYM. Three levels of recommended dose (150:80:80 NPK Kg/ha) of NPK i.e., $100 \%, 75 \%$ and $50 \%$ were included. Twothird of NPK and whole amount of FYM was applied irrespective of treatments during field preparation. All intercultural operations, such as weeding, irrigation, and Pest and disease management were done as and when required.

The observations were recorded on five randomly selected plants from each plot on different growth and yield parameters. The observation regarding the plant height and plant spread in both direction were recorded at 75 days after transplanting (DAP), number of primary and secondary branches were also counted at 75 DAP. Harvesting was done through 6-8 picking at weekly interval. After completion of harvesting the projected yield per hectare was calculated on the basis of yield per plot considering $75 \%$ area occupied by chilli in the present experiment and rest was utilized for channels, ridges etc. Data recorded for both years were pooled together and analysed statistically to express the result.

\section{Results and Discussion}

The experimental results (Table 1) revealed a number of interesting features of growth, yield attributing parameters and yield of chilli. 
Table.1 Effect of biofertilizers with graded levels of inorganic fertilizers on growth and yield of chilli (two years pooled data)

\begin{tabular}{|c|c|c|c|c|c|c|c|c|c|c|}
\hline & \multirow[b]{2}{*}{ Treatment } & \multirow{2}{*}{$\begin{array}{c}\text { Plant height } \\
(\mathrm{cm}) \\
75 \\
\text { DAP }\end{array}$} & \multicolumn{2}{|c|}{$\begin{array}{c}\text { Plant spread } \\
\text { (75 DAP) }\end{array}$} & \multicolumn{2}{|c|}{ Branches } & \multirow{2}{*}{$\begin{array}{c}\text { Days to } \\
\text { first } \\
\text { flowering }\end{array}$} & \multirow{2}{*}{$\begin{array}{c}\text { Number } \\
\text { of } \\
\text { fruits/pla } \\
\text { nt }\end{array}$} & \multirow{2}{*}{$\begin{array}{c}\text { Yield/ } \\
\text { Plant } \\
\text { (g) }\end{array}$} & \multirow{2}{*}{$\begin{array}{c}\text { Projected } \\
\text { yield/ha } \\
\text { (t) }\end{array}$} \\
\hline & & & $\begin{array}{l}\text { East-West } \\
(\mathrm{cm})\end{array}$ & $\begin{array}{c}\text { North- } \\
\text { South }(\mathrm{cm})\end{array}$ & Primary & secondary & & & & \\
\hline $\mathrm{T}_{1}$ & NPK $(100 \%)+$ Azot.+ VAM + KM & 48.16 & 33.70 & 31.80 & 4.10 & 13.34 & 46.25 & 81.76 & 160.66 & 5.76 \\
\hline $\mathrm{T}_{2}$ & NPK $(100 \%)+$ Azot. + PSB + KM & 51.27 & 32.33 & 31.37 & 3.97 & 14.37 & 39.82 & 92.63 & 164.42 & 6.04 \\
\hline $\mathrm{T}_{3}$ & NPK $(100 \%)+$ Azos. + VAM + KM & 54.70 & 35.37 & 32.53 & 4.54 & 16.70 & 38.26 & 101.73 & 169.46 & 6.35 \\
\hline $\mathrm{T}_{4}$ & NPK $(100 \%)+$ Azos. + PSB + KM & 52.83 & 33.23 & 32.63 & 4.07 & 14.86 & 42.53 & 94.87 & 163.00 & 5.91 \\
\hline $\mathrm{T}_{5}$ & NPK $(75 \%)+$ Azot. + VAM + KM & 51.00 & 31.17 & 30.57 & 3.60 & 15.44 & 39.28 & 82.17 & 150.76 & 5.58 \\
\hline $\mathrm{T}_{6}$ & NPK $(75 \%)+$ Azot. + PSB + KM & 55.50 & 34.10 & 32.47 & 3.64 & 14.04 & 47.56 & 84.88 & 146.36 & 5.41 \\
\hline $\mathrm{T}_{7}$ & NPK $(75 \%)+$ Azos. + VAM + KM & 46.07 & 31.90 & 32.27 & 3.94 & 13.48 & 43.14 & 88.97 & 152.76 & 5.69 \\
\hline $\mathrm{T}_{8}$ & NPK $(75 \%)+$ Azos. + PSB + KM & 53.30 & 35.93 & 34.26 & 3.80 & 12.30 & 41.38 & 86.25 & 151.68 & 5.56 \\
\hline $\mathrm{T}_{9}$ & NPK $(50 \%)+$ Azot. + VAM + KM & 51.77 & 29.50 & 30.24 & 3.50 & 14.30 & 38.72 & 79.48 & 135.20 & 4.36 \\
\hline $\mathrm{T}_{10}$ & NPK $(50 \%)+$ Azot. + PSB + KM & 49.50 & 32.33 & 31.77 & 3.04 & 12.27 & 40.13 & 77.54 & 127.64 & 4.50 \\
\hline $\mathrm{T}_{11}$ & NPK $(50 \%)+$ Azos. + VAM + KM & 43.73 & 31.10 & 31.24 & 4.01 & 13.68 & 41.28 & 81.40 & 132.60 & 4.83 \\
\hline $\mathrm{T}_{12}$ & NPK $(50 \%)+$ Azos. + PSB + KM & 51.03 & 30.47 & 29.27 & 3.13 & 13.90 & 46.75 & 73.08 & 134.84 & 4.64 \\
\hline $\mathrm{T}_{13}$ & NPK $(100 \%)$ & 45.90 & 31.67 & 30.64 & 3.20 & 12.60 & 43.76 & 74.84 & 133.02 & 4.78 \\
\hline & S. Em $( \pm)$ & 2.041 & 1.760 & 2.067 & 0.235 & 0.654 & 1.425 & 2.640 & 0.213 & 0.014 \\
\hline & C.D. $(P=0.05)$ & 5.423 & 4.893 & 4.513 & 1.002 & 2.011 & 4.532 & 7.621 & 0.954 & 0.124 \\
\hline
\end{tabular}

Azot. $=$ Azotobacter, Azos. $=$ Azospirillum, VAM= Vesicular arbuscular mycorrhiza, $\mathrm{PSB}=$ Phosphorus solubilising bacteria, $\mathrm{KM}=$ Potassium mobilize DAP=Day after planting 
Among different treatments, the maximum plant height $(55.55 \mathrm{~cm})$ was reported in NPK $(75 \%)+$ Azotobactor + PSB + KM and Plant spread in both East-West $(35.93 \mathrm{~cm})$ and North-South $(34.26 \mathrm{~cm})$ direction were recorded in NPK $(75 \%)+$ Azospirillum + PSB + KM. The number of both primary (4.54), and secondary (16.70) branches/plant, earliest flower initiation (38.26 days), number of fruits per plant (101.73), yield/plant (169.46g) and projected yield (6.35 t/ha) were observed in plants raised under NPK $(100 \%)+$ Azospirillum + VAM + KM.

The treatment combination of NPK $(100 \%)+$ Azospirillum +VAM $+\mathrm{KM}$ recorded maximum yield $(6.35 \mathrm{t} / \mathrm{ha})$ followed by NPK $(100 \%)+$ Azotobactor + PSB + KM (6.04 t/ha) and NPK (100\%) + Azospirillum + PSB $+\mathrm{KM}(5.91 \mathrm{t} / \mathrm{ha})$ as compared to $4.98 \mathrm{t} / \mathrm{ha}$ under NPK (100\%). For yield maximization point of view, the most effective treatment was NPK $(100 \%)+$ Azospirillum + VAM + KM followed by NPK $(100 \%)+$ Azotobactor $+\mathrm{PSB}+\mathrm{KM}$ and NPK $(100 \%)+$ Azospirillum + PSB + KM under alluvial plans of west Bengal for production of chilli.

The increase in yield was largely as a consequence of the cumulative effect of plant growth characters. Similar growth and yield increase were recorded earlier with combined inoculation of biofertilizers in chilli (Sable et al., 2007; Khan and Chattopadhyay, 2009 and Wange and Kale, 2004), The increase in growth attributes due to increase fertilizers may be ascertained due to increase amount of nutrients such as nitrogen, phosphorus and potassium in plants leading to increase formation of plant metabolites that help to build up the plant tissues (Childer, 1996).

The experimental results indicated that combination Azospirillum and VAM was superior as compared to other combinations. The better efficiency of Azospirillum in chilli was also reported by Paramaguru and Natarajan (1993) and Jeevansab (2000). Other than enhancing $\mathrm{P}$ availability, uptake of miner elements like $\mathrm{Zn}, \mathrm{Cu}$ and $\mathrm{Mn}$ and hormonal production have also been attributed to VAM inoculated plants in increasing plant growth. (Sukhada, 1987), Bagyaraj and Sreeramulu (1982) are reported that mycorrhizal inoculation enhanced significantly the yield of green chilli and reduced the application of phosphatic fertilizers by 50 per cent. The yield under treatment combination NP $(100 \%)$ + biofertilizers were more or at par with NPK $(100 \%)$ alone, indicating there is a chance of saving of $25 \%$ inorganic NP through biofertilizers. These results are in conformity with the findings of Gowda et al., (2002) and Khan and Chattopadhyay (2009) they also recorded the saving of $25 \%$ inorganic fertilizers through biofertilizers.

For yield maximization point of view, the most effective treatment was NPK $(100 \%)+$ Azospirillum + VAM + KM followed by NPK $(100 \%)+$ Azotobactor + PSB + KM and NPK $(100 \%)+$ Azospirillum + PSB + KM under alluvial plans of west Bengal.

\section{References}

Bagyaraj, D.J. and Sreeramulu, K.R. 1982. Pre inoculation with VA mycorrhiza improves growth and yield of chilli transplanted in the field and saves phosphatic fertilizer. Plant Soil, 69: 375-81.

Childer, N.F. 1996. Fruit Nutrition. Horticultural Publications. Rntgert State University, Nichole Avenue, New Jwersiy.UAS

Friedrich, S., Platonova, N.P., Karavaiko, G. I., Stichel, E. and Glombitze, F. 1991. Chemicals and microbiological solubilization of silicates. Acta Biotech., 11: 187-96.

Gowda, K.K., Sajan, K.M., Kumar, S.N. and 
Sreeramu, B.S. 2002. Effect of biofertilizers on growth and yield of chilli (Capsicum annuum L.) cv Byadagi Dabba at different levels of nitrogen and phosphorus. J. Spices Aromatic Crops, 11(1): 58-61.

Jeevansab. 2000. Effect of nutrient sources on growth, yield and quality of capsicum (cv. California wonder) grown under different environments. M.Sc. Agri.) Thesis, Univ. Agri. Sci. Dharwad.

Khan, S. and Chattopadhyay, N. 2009. Effect of inorganic and biofertilizers on chilli. J. Crop Weed, 5(1): 195-200.

Mondal, T., Ghanti, P., Mahato, B., Mondal, A. R. and Thapa, U. 2003. Effect of spacing and biofertilizer on yield and yield attributes of direct sown Chilli $(C$. annuum L. cv. Bona Lanka. Env. Eco., 21: 712-15.

Paramaguru, P. and Natarajan, S. 1993. Effect of Azosperillum on growth and yield of chilli (Capsicum annuum L.) grown under semi-dry conditions. South Indian Hort., 41(2): 80-83.

Patel, B.N., Solanki, M.P., Patel, S.R. and Desai, J.R. 2011. Effect of biofertilizers on growth, physiological parameters, yield and quality of brinjal cv. Swati Ravaiya. Indian J.Hort., 68: 370-74.

Sable, C.R., Ghuge, T.D., Jadhav, S.B. and Gore, A.K. 2007. Impact of organic sources on uptake, quality and availability of nutrients after harvest of tomato. J. Soils Crops, 17(2): 284-87.

Sukhada, M. and Balaji, S. 1996. A note on nursery application of Vesicular Arbuscular Mycorrhiza on growth and yield of chilli (Capsicum annuum L). Veg. Sci., 23: 103-05.

Wange, S.S. and Kale, R.H. 2004. Effect of bio-fertilizers under graded nitrogen levels of brinjal crop. J. Soils Crops, 14(1): 9-11.

Warrier, P.K. 1989. Spice in Ayurveda. Indian Spices, 26(2): 21-23.

\section{How to cite this article:}

Holebasappa Kumbar, A. Chandini Raj and Hore, J.K. 2017. Effect of Biofertilizers and Inorganic Fertilizers on Growth and Yield of Chilli (Capsicum annuum L.). Int.J.Curr.Microbiol.App.Sci. 6(7): 1564-1568. doi: https://doi.org/10.20546/ijcmas.2017.607.187 